\title{
A Statistical Study on Some Micromorphological Characters
}

\author{
Alperen Özdemir ${ }^{1}$, Ali Özdemir ${ }^{2 *}$ \\ ${ }^{1}$ Georgia Institute of Technology, Department of Mathematics, Atlanta, USA, (ORCID: 0000-0003-2730-7240), alperenozdemir678@gmail.com \\ $2^{*}$ Manisa Celal Bayar University, Faculty of Arts and Sciences, Department of Mathematics, Manisa, Turkey, (ORCID: 0000-0001-9330-7084), \\ acaozdemir@gmail.com
}

(2nd International Conference on Applied Engineering and Natural Sciences ICAENS 2022, March 10-13, 2022)

(DOI: 10.31590/ejosat.1077841)

ATIF/REFERENCE: Özdemir, A. \& Özdemir, A. (2022). A Statistical Study on Some Micromorphological Characters. Avrupa Bilim ve Teknoloji Dergisi, (34), 135-141.

\begin{abstract}
In this study, the micromorphological features of 19 Salvia L. taxa belonging to the Lamiaceae family were compared statistically. For micromorphological studies, the manual cross sections were prepared. The sections were colored using safranin and fast-green dyes and after that, photographed by different magnification of light microscope. The data obtained from the micromorphological features of the investigated samples were turned into tables and were used for statistical studies. Significance level of the differences between the taxa and micromorphological characters were evaluated by Analysis of variance (Regression Analysis) and Pearson's correlation. The differences were also assessed by the one-way ANOVA test. As the results of this study show that the quantitative micromorphological characters such as lower epidermis width and lower epidermis length are the most appropriate taxonomical characters that can be used to separate taxa. By this study, it has been found that the results from numerical analysis of micromorphological characters can provide additional evidence for the recognition of the taxa. In addition, the results showed that the investigated taxa also could be distinguished from each other not only by their morphological features but numerical micromorphological anatomical characters as well. Statistical analyses were performed using the MINITAB software package.
\end{abstract}

Keywords: Statistical comparison, Micromorphological characters, Salvia.

\section{Bazı Mikromorfolojik Karakterler Üzerine İstatistiksel Bir Çalışma}

\section{Öz}

Bu çalışmada, Lamiaceae familyasına ait 19 Salvia L. taksonunun bazı mikromorfolojik özellikleri istatistiksel olarak karşılaştırıldı. Mikromorfolojik çalışmalar için örneklerin yapraklarından el kesitleri alındı. Kesitler safranin ve fast-green boyaları ile renklendirildikten sonra 1şık mikroskobunda farklı büyütmelerde fotoğraflandı. İncelenen örneklerin mikromorfolojik özelliklerinden elde edilen veriler tablolara dönüştürülerek istatistiksel çalışmalarda kullanılmıştır. Taksonlar ve mikromorfolojik karakterler arasındaki istatistiki farklılıkların önemlilik düzeyi, Varyans Analizi (Regresyon Analizi) ve Pearson korelasyonu ile değerlendirildi. Farklılıklar ayrıca tek yönlü ANOVA testi ile değerlendirildi. Çalışmanın sonucu, alt epidermis boyu ve alt epidermis eni gibi kantitatif mikromorfolojik karakterlerin, taksonları ayırmak için kullanılabilecek en uygun taksonomik karakterler olduğunu göstermektedir. Bu çalışma ile mikromorfolojik karakterlerin sayısal analizinden elde edilen sonuçların taksonların tanınması için ek kanıt sağlayabileceği bulunmuştur. Ayrıca sonuçlar, incelenen taksonların sadece morfolojik özellikleri ile değil aynı zamanda sayısal mikromorfolojik anatomik karakterleri ile de birbirinden ayırt edilebildiğini göstermiştir. Çalışmada istatistiksel analizler MINITAB yazılım paketi kullanılarak yapildı.

Anahtar kelimeler: İstatistik karşıllaştırma, Mikromorfolojik karakterler, Salvia 


\section{Introduction}

Lamiaceae is a family rich in wild aromatic plant species and antioxidant compounds beneficial to humans [1]. Salvia L. is one of the largest belongings to the Lamiaceae [2]. It is known that Salvia taxa, which have antibacterial, carminative, stimulant, diuretic, and spasmolytic properties, have been used for treatment since the earliest times [3]- [6].

Micromorphological studies of Lamiaceae have been carried out by many authors; however, numerical studies carried out on the taxa were limited [7]- [9].

We have not found any studies on statistical comparison of numerical micromorphological features used in this study, such as this one we have done. The micromorphological variations in the taxa have been investigated by means of numerical methods. Results have been supported by tables. The purpose is to determine statistically the closeness of the taxa with the help of numerical micromorphological characters.

\section{Material and Method}

The samples were collected from natural populations. Taxonomic description of the plant was made according to Davis [10].

Some leaf micromorphological characters were selected for the numerical analysis (Table 1). This selection was based on the variations of the anatomical data. The reason for choosing the micromorphological characters evaluated for statistical study is that these characters variability among different taxa and can be used in common for taxonomic identification. Measurements were made in these structures. Minimum, maximum, average and standard error values were determined, and these values were turned into tables. Characters were coded as 1, 2, 3, 4 and the taxa were coded as A, B, C, D, E, F, G, H, I, J, K, L, M, N, O, P, R, S, T (Table 1).

Significance level of the differences between the taxa and micromorphological characters were evaluated by Analysis of variance (Regression Analysis) and Pearson's correlation. The differences were also assessed by the one-way ANOVA test. Statistical analyses were performed using the MINITAB software package (Table 2-7).

\section{Conclusion and Discussion}

The results of present research were shown that the leaf sections of the taxa are similar with the general characteristics. Epidermis cells, which are leaf protective tissues of taxa, were observed to be covered with cuticles of different thicknesses in all taxa examined. The epidermis cells covering both the lower and upper surfaces of the leaves were arranged in different and similar sizes and shapes, depending on the taxa studied.

The minimal and maximal values of micromorphological characteristics of taxa as well as arithmetical means were shown in Table 1. Significance level of the differences between the taxa and micromorphological characters were evaluated by

Analysis of variance (Regression Analysis) and Pearson's correlation.
The differences were also assessed by the one-way ANOVA test. The results of the statistical analyzes were shown in Tables 2, 3, $4,5,6$ and 7 .

When taxa and micromorphological characters are compared in based on One-way ANOVA test, the significant difference (sig. $=0,009$ ) has been found at level $p<0.05$ among the micromorphological characters, Table 2 shows. Furthermore, a significant difference $($ sig. $=0,017$ ) has been found among the investigated taxa at level $\mathrm{p}<0.01$ based on One-way ANOVA test (Table 3)

According to Table 4 based on Pearson correlation analysis, upper epidermis length (sig. $=0.004)$ and lower epidermis width $($ sig. $=0.050)$ /upper epidermis width display significant differences at level $\mathrm{p}<0.05$ and $\mathrm{P}<0.01$. According to the same table upper epidermis length $($ sig. $=0.012)$ and lower epidermis width $(\mathrm{sig} .=0.003)$ /lower epidermis length display significant differences at level $\mathrm{p}<0.05$ and $\mathrm{P}<0.01$.

Similarly, according to Table 5 based on Analysis of Variance, there are important correlations among the micromorphological characters investigated taxa, shown as $1-2,1-3$ and 3-4 (respectively sig. $=0.004,0.052$ and 0.03 ) at levels of 0.01 and 0.05 (Table 5).

On the other hand, when the results obtained by comparing the taxa with both different statistical methods are examined, the following results were obtained.

According to Table 6 based on there are important correlations among investigated taxa, shown as (A-F, K, M); (B-D, E, F, H, J, $\mathrm{K}, \mathrm{M})$; (C-G); (D-F, G, H, J, K, P); (E-J); (F-J, K); (G-P); (H-J, O, P) $(\mathrm{J}-\mathrm{K}, \mathrm{N}, \mathrm{O}, \mathrm{P}) ;(\mathrm{K}-\mathrm{N}, \mathrm{R}) ;(\mathrm{M}-\mathrm{R}, \mathrm{T})$ and $(\mathrm{O}-\mathrm{P})$ at levels of 0.01 and 0.05 (Table 6).

Similarly, according to Table 7 that based on Analysis of Variance there are important correlations among the investigated taxa, shown as (A-F, K, M); (B-D, E, F, H, K); (D-F, G, H, K, P); (F-B, $\mathrm{R})$; (G-P); (H-O, P); (J-B, D, F, K, O, P); (K-F, R); (M-R) and (O$\mathrm{P}$ ) at levels of 0.01 and 0.05 (Table 7).

On the other hand, according to both the method for investigated taxa coded as A-T, positive statistically significant correlations between (A-F, K, M); (B-D, E, F, H, K, M); (C-G); (D-F, G, H, K, P); (E-J); (F-J, K); (G-P); (H-O, P) (J-K, O, P); (K$\mathrm{R})$; (M-R) and (O-P) at levels of 0.01 and 0.05 were observed (Table 6,7). The highest similarity (for both the method) was revealed between $\mathrm{F}$ and $\mathrm{K}$ as sig. $=0.001$.

This study aims via numerical analyses of the variations in the leaf micromorphological characteristics, to identify similarities and differences of 19 taxa. Another aim of the study is to define the variability of the investigated taxa and introduce the diagnostic leaf micromorphological characters useful in separation of the taxa.

In the literature, many researchers showed the importance of the micromorphological characters [7], [8], [11]. Also, Metcalf and Chalk pointed to the importance of leaf anatomy characters [12].

Kocsis et al., have studied with the Rubiaceae family and have examined the anatomy of the petioles and showed the importance it has in terms of taxonomic classification [13]. Olowokudejo studied the miromorphological features of 46 taxa belonging to the Cruciferae family and reported the importance micromorphological features [14]. 
Table 1. The measurements of micromorphological characters of investigated taxa

\begin{tabular}{|c|c|c|c|c|c|c|c|c|c|c|c|c|c|}
\hline & & \multicolumn{6}{|c|}{ Upper epidermis } & \multicolumn{6}{|c|}{ Lower epidermis } \\
\hline & \multirow[t]{2}{*}{ Taxon } & \multicolumn{3}{|c|}{$\begin{array}{c}1 \\
\text { Widht }(\mu \mathrm{m})\end{array}$} & \multicolumn{3}{|c|}{$\begin{array}{c}2 \\
\text { Lenght }(\mu \mathrm{m})\end{array}$} & \multicolumn{3}{|c|}{$\begin{array}{c}3 \\
\text { Widht }(\mu \mathrm{m})\end{array}$} & \multicolumn{3}{|c|}{$\begin{array}{c}4 \\
\text { Lenght }(\mu \mathrm{m})\end{array}$} \\
\hline & & Mean & & SD & Mean & & SD & Mean & & SD & Mean & & SD \\
\hline $\mathbf{A}$ & $\begin{array}{l}\text { S. recognita Fisch. Et Mey. } \\
\text { En. }\end{array}$ & 15.10 & \pm & 2.02 & 17.50 & \pm & 5.60 & 24.40 & \pm & 4.00 & 27.30 & \pm & 2.00 \\
\hline $\mathbf{B}$ & S. bracteate Banks Et Sol. & 27.20 & \pm & 2.10 & 23.40 & \pm & 2.10 & 32.50 & \pm & 8.10 & 36.40 & \pm & 6.10 \\
\hline $\mathbf{C}$ & $\begin{array}{l}\text { S. huberi Hedge } \\
\text { En. }\end{array}$ & 31.30 & \pm & 3.60 & 23.50 & \pm & 5.30 & 34.50 & \pm & 2.40 & 14.40 & \pm & 3.40 \\
\hline D & $\begin{array}{l}\text { S. wiedemannii Boiss. } \\
\text { En. }\end{array}$ & 22.00 & \pm & 2.10 & 15.10 & \pm & 2.10 & 34.60 & \pm & 2.10 & 38.30 & \pm & 1.10 \\
\hline $\mathbf{E}$ & $\begin{array}{l}\text { S. tchihatcheffii (Fisch. Et Mey.) } \\
\text { Boiss. En. }\end{array}$ & 12.30 & \pm & 6.20 & 18.50 & \pm & 3.20 & 24.50 & \pm & 5.00 & 14.50 & \pm & 7.00 \\
\hline $\mathbf{F}$ & $\begin{array}{l}\text { S. suffruticosa Montbret Et } \\
\text { Aucher Ex Bentham }\end{array}$ & 13.10 & \pm & 9.50 & 10.10 & \pm & 7.20 & 29.50 & \pm & 3.80 & 37.40 & \pm & 3.20 \\
\hline G & $\begin{array}{l}\text { S. cadmica Boiss. } \\
\text { En. }\end{array}$ & 40.30 & \pm & 6.10 & 28.30 & \pm & 2.10 & 54.50 & \pm & 5.20 & 53.10 & \pm & 6.10 \\
\hline $\mathbf{H}$ & $\begin{array}{l}\text { S. smrynaea Boiss. } \\
\text { En. }\end{array}$ & 31.00 & \pm & 3.20 & 23.50 & \pm & 3.40 & 34.50 & \pm & 2.60 & 38.10 & \pm & 4.30 \\
\hline $\mathbf{I}$ & $\begin{array}{l}\text { S. blepharochlaena Hedge Et } \\
\text { Hub-Mor. En. }\end{array}$ & 18.10 & \pm & 4.70 & 22.50 & \pm & 7.70 & 20.70 & \pm & 5.20 & 36.20 & \pm & 2.60 \\
\hline $\mathbf{J}$ & S. multicaulis Vahl & 25.40 & \pm & 2.20 & 17.20 & \pm & 4.10 & 32.50 & \pm & 5.30 & 39.30 & \pm & 4.10 \\
\hline $\mathbf{K}$ & $\begin{array}{l}\text { S. cryptantha Montbret Et } \\
\text { Aucher Ex Bentham En. }\end{array}$ & 21.00 & \pm & 4.30 & 17.30 & \pm & 3.10 & 35.50 & \pm & 3.20 & 42.40 & \pm & 6.70 \\
\hline $\mathbf{L}$ & S. viridis $\mathrm{L}$. & 34.40 & \pm & 19.6 & 53.60 & \pm & 33.5 & 24.40 & \pm & 15.1 & 33.30 & \pm & 14.1 \\
\hline $\mathbf{M}$ & S. sclarea L. & 30.13 & \pm & 3.30 & 27.20 & \pm & 2.30 & 21.50 & \pm & 5.50 & 17.20 & \pm & 3.60 \\
\hline $\mathbf{N}$ & $\begin{array}{l}\text { S. chrysophylla Stapf } \\
\text { En. }\end{array}$ & 23.10 & \pm & 2.30 & 30.50 & \pm & 2.20 & 20.10 & \pm & 6.20 & 32.10 & \pm & 4.30 \\
\hline $\mathbf{O}$ & S. microstegia Bo1ss. Et Bal. & 19.10 & \pm & 3.10 & 12.10 & \pm & 3.10 & 20.35 & \pm & 2.60 & 23.40 & \pm & 3.10 \\
\hline $\mathbf{P}$ & S. limbate C. A. Meyer & 23.10 & \pm & 4.90 & 18.50 & \pm & 4.10 & 28.10 & \pm & 3.20 & 31.30 & \pm & 6.20 \\
\hline $\mathbf{R}$ & S. forskahlei L. & 18.10 & \pm & 7.30 & 21.30 & \pm & 2.10 & 33.50 & \pm & 6.70 & 38.40 & \pm & 5.10 \\
\hline $\mathbf{S}$ & S. argentea $\mathrm{L}$. & 29.10 & \pm & 19.2 & 24.30 & \pm & 8.10 & 21.80 & \pm & 16.7 & 19.40 & \pm & 9.10 \\
\hline $\mathbf{T}$ & $\begin{array}{l}\text { S. halophila Hedge } \\
\text { En. }\end{array}$ & 28.30 & \pm & 1.30 & 24.40 & \pm & 2.20 & 25.50 & \pm & 3.40 & 28.40 & \pm & 6.70 \\
\hline
\end{tabular}

SD: Standard Deviation. 1-4: Character Codes. A-T: Taxon Codes. En.: Endemic. $\boldsymbol{\mu m}$ : Micrometer

Table 2. One-way ANOVA test based on micromorphological characters.

\begin{tabular}{|c|c|c|c|c|c|c|}
\hline Source & DF & SS & MS & $\mathbf{F}$ & $\mathbf{P}$ & Significance \\
\hline Factor & 3 & 966,9 & 322,3 & 4,11 & 0,009 & $\star \star$ \\
\hline Error & 72 & 5642,2 & 78,4 & & & \\
\hline Total & 75 & 6609,1 & & & & \\
\hline$S=8,8$ & & $\mathrm{R}-\mathrm{Sq}=$ & $14,63 \%$ & $\mathrm{R}-\mathrm{Sc}$ & $(\operatorname{adj})=$ & $=11,07 \%$ \\
\hline
\end{tabular}

DF: Degree of Freedom SS: Sum of Square

MS: MS: Mean Square F: F Value P: Probability

Table 3. One-way ANOVA test based on the investigated taxon.

\begin{tabular}{|c|c|c|c|c|c|c|}
\hline Source & DF & SS & MS & $\mathbf{F}$ & $\mathbf{P}$ & Significance \\
\hline Factor & 18 & 2642,1 & 146,8 & 2,11 & 0,017 & * \\
\hline Error & 57 & 3967,0 & 69,6 & & & \\
\hline Total & 75 & 6609,1 & & & & \\
\hline$S=8,3$ & & $\mathrm{R}-\mathrm{Sq}=$ & $39,98 \%$ & $\mathrm{R}-\mathrm{Sc}$ & $(\operatorname{adj})$ & $=21,02 \%$ \\
\hline
\end{tabular}

DF: Degree of Freedom SS: Sum of Square

MS: MS: Mean Square F: F Value P: Probability 
Table 4. Pearson correlation based on the micromorphological features

1

20,634

$0,004 * *$

$30,452 \quad 0,056$

$0,050 * 0,821$

$4 \quad 0,190 \quad 0,012 * 0,643$

$0,437 \quad 0,960 \quad 0,003 * *$

Significant at the level of $\mathrm{P}<0.05$. ** Significant at the level of 0.01 .

Abbreviations: 1-2: Codes of micromorphological features

Table 5. Correlation between micromorphological features (Analysis of Variance)

\begin{tabular}{clllc}
\hline Source & MS & F-value & Probability & Significance \\
\hline $1-2$ & 401,08 & 11,41 & 0,004 & $* *$ \\
$1-3$ & 203,64 & 04,36 & 0,052 & $*$ \\
$1-4$ & 035,91 & 00,63 & 0,437 & NS \\
$2-3$ & 004,71 & 00,05 & 0,821 & NS \\
$2-4$ & 00,230 & 00,02 & 0,960 & NS \\
$3-4$ & 500,49 & 11,97 & 0,003 & $* *$
\end{tabular}

MS: Mean Square; $* \mathrm{P}<.05 ; * * \mathrm{P}<.01$.

1-2: Codes of anatomical features; NS: Not Significant.

Table 6. Pearson correlation based on the investigated taxon

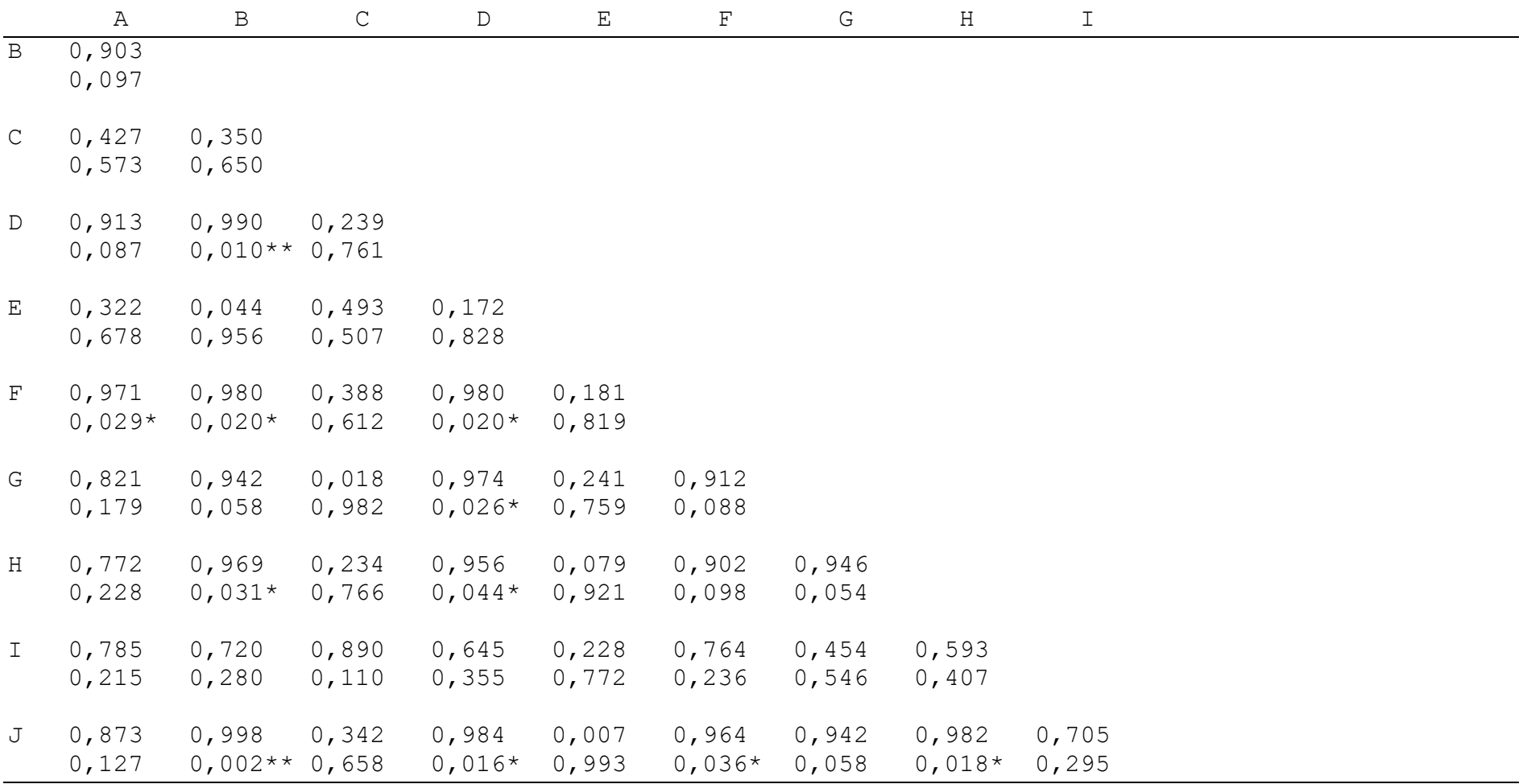

Significant at the level of $\mathrm{P}<0.05$. ** Significant at the level of 0.01 .

Abbreviations: A-T: Codes of the investigated taxon 
Table 6. (Continued)

\begin{tabular}{|c|c|c|c|c|c|c|c|c|c|}
\hline & A & B & C & D & $\mathrm{E}$ & $\mathrm{F}$ & $\mathrm{G}$ & $\mathrm{H}$ & I \\
\hline $\mathrm{K}$ & $\begin{array}{l}0,960 \\
0,040 *\end{array}$ & $\begin{array}{l}0,987 \\
0,013 *\end{array}$ & $\begin{array}{l}0,364 \\
0,636\end{array}$ & $\begin{array}{l}0,988 \\
0,012 *\end{array}$ & $\begin{array}{c}0,166 \\
0,834\end{array}$ & $\begin{array}{l}0,999 \\
0,001 * *\end{array}$ & $\begin{array}{l}0,927 \\
0,073\end{array}$ & $\begin{array}{l}0,920 \\
0,080\end{array}$ & $\begin{array}{l}0,745 \\
0,255\end{array}$ \\
\hline $\mathrm{M}$ & $\begin{array}{l}0,995 \\
0,005 * *\end{array}$ & $\begin{array}{l}0,876 \\
0,124\end{array}$ & $\begin{array}{l}0,501 \\
0,499\end{array}$ & $\begin{array}{l}0,878 \\
0,122\end{array}$ & $\begin{array}{l}0,291 \\
0,709\end{array}$ & $\begin{array}{l}0,953 \\
0,047\end{array}$ & $\begin{array}{l}0,766 \\
0,234\end{array}$ & $\begin{array}{l}0,731 \\
0,269\end{array}$ & $\begin{array}{l}0,830 \\
0,170\end{array}$ \\
\hline $\mathrm{N}$ & $\begin{array}{l}0,164 \\
0,836\end{array}$ & $\begin{array}{l}0,010 \\
0,990\end{array}$ & $\begin{array}{l}0,925 \\
0,075\end{array}$ & $\begin{array}{l}0,114 \\
0,886\end{array}$ & $\begin{array}{l}0,426 \\
0,574\end{array}$ & $\begin{array}{l}0,063 \\
0,937\end{array}$ & $\begin{array}{l}0,337 \\
0,663\end{array}$ & $\begin{array}{l}0,151 \\
0,849\end{array}$ & $\begin{array}{l}0,685 \\
0,315\end{array}$ \\
\hline 0 & $\begin{array}{l}0,687 \\
0,313\end{array}$ & $\begin{array}{l}0,932 \\
0,068\end{array}$ & $\begin{array}{l}0,195 \\
0,805\end{array}$ & $\begin{array}{l}0,913 \\
0,087\end{array}$ & $\begin{array}{l}0,162 \\
0,838\end{array}$ & $\begin{array}{l}0,841 \\
0,159\end{array}$ & $\begin{array}{l}0,918 \\
0,082\end{array}$ & $\begin{array}{l}0,992 \\
0,008 * *\end{array}$ & $\begin{array}{l}0,532 \\
0,468\end{array}$ \\
\hline S & $\begin{array}{l}0,929 \\
0,071\end{array}$ & $\begin{array}{l}0,697 \\
0,303\end{array}$ & $\begin{array}{l}0,577 \\
0,423\end{array}$ & $\begin{array}{l}0,698 \\
0,302\end{array}$ & $\begin{array}{l}0,360 \\
0,640\end{array}$ & $\begin{array}{l}0,821 \\
0,179\end{array}$ & $\begin{array}{l}0,552 \\
0,448\end{array}$ & $\begin{array}{l}0,499 \\
0,501\end{array}$ & $\begin{array}{l}0,826 \\
0,174\end{array}$ \\
\hline $\mathrm{T}$ & $\begin{array}{l}0,051 \\
0,949\end{array}$ & $\begin{array}{l}0,406 \\
0,594\end{array}$ & $\begin{array}{l}0,439 \\
0,561\end{array}$ & $\begin{array}{l}0,299 \\
0,701 \\
\end{array}$ & $\begin{array}{l}0,873 \\
0,127\end{array}$ & $\begin{array}{l}0,246 \\
0,754 \\
\end{array}$ & $\begin{array}{l}0,258 \\
0,742 \\
\end{array}$ & $\begin{array}{l}0,545 \\
0,455\end{array}$ & $\begin{array}{l}0,396 \\
0,604 \\
\end{array}$ \\
\hline
\end{tabular}

Significant at the level of $\mathrm{P}<0.05$. $* *$ Significant at the level of 0.01 .

Abbreviations: A-T: Codes of the investigated taxon

Table 6. (Continued)

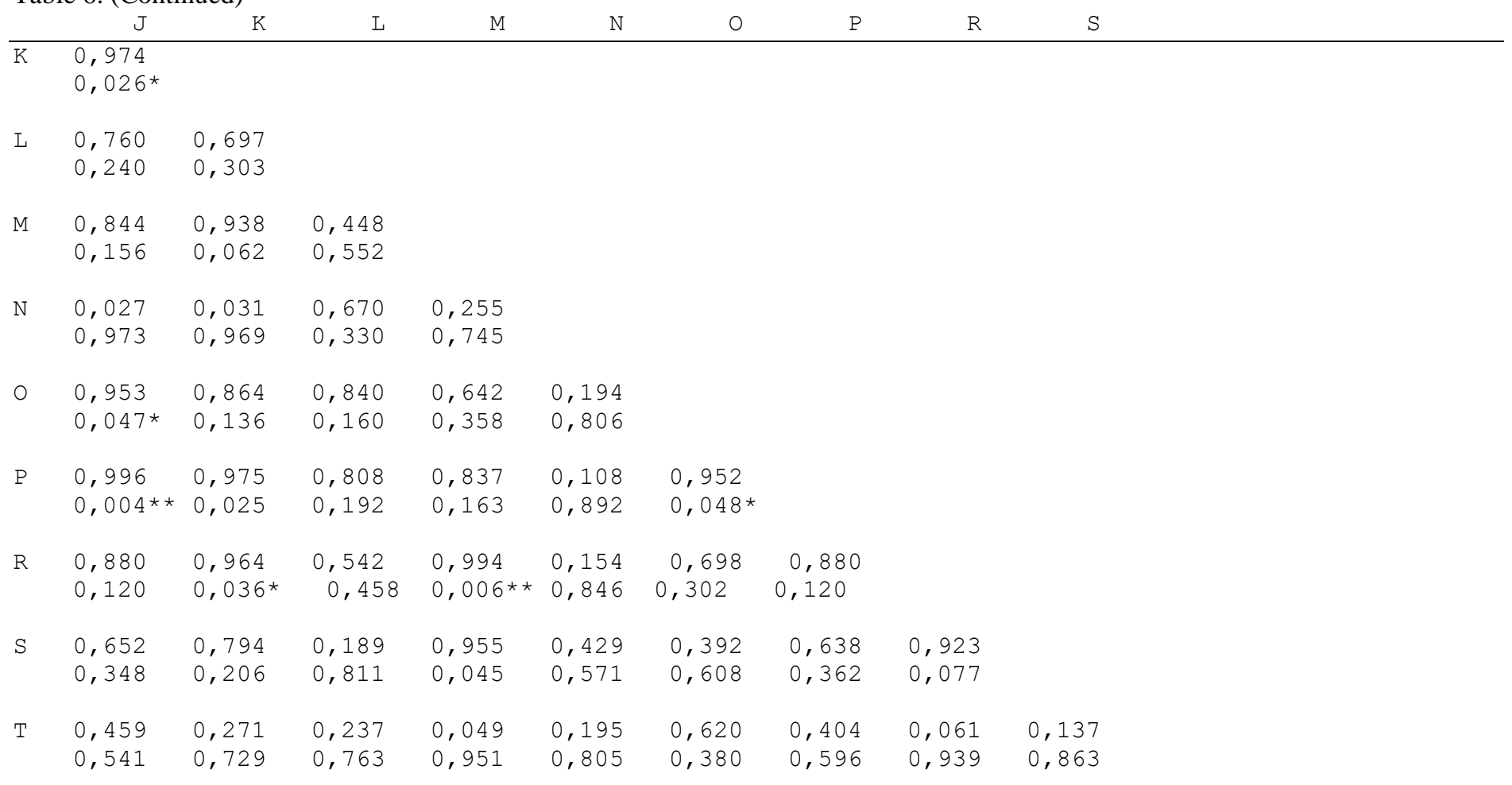

Significant at the level of $\mathrm{P}<0.05$. ** Significant at the level of 0.01 .

Abbreviations: A-T: Codes of the investigated taxon 
Table 7. Correlation between taxon (Analysis of Variance).

\begin{tabular}{|c|c|c|c|c|}
\hline Source & MS & F-value & Probability & Significance \\
\hline A-F & 91,179 & 32,730 & 0,029 & $*$ \\
\hline A-K & 89,080 & 23,236 & 0,047 & $*$ \\
\hline A-M & 95,860 & 217,30 & 0,005 & $* *$ \\
\hline B-D & 95,115 & 100,92 & 0,010 & $* *$ \\
\hline B-F & 93,113 & 47,910 & 0,020 & $*$ \\
\hline B-H & 91,116 & 30,970 & 0,031 & $*$ \\
\hline B-K & 94,503 & 75,708 & 0,013 & $*$ \\
\hline B-P & 96,103 & 194,00 & 0,005 & $* *$ \\
\hline $\mathrm{D}-\mathrm{F}$ & 325,23 & 48,000 & 0,020 & $*$ \\
\hline $\mathrm{D}-\mathrm{G}$ & 321,04 & 36,260 & 0,028 & $*$ \\
\hline D-P & 334,30 & 150,11 & 0,007 & $* *$ \\
\hline D-H & 391,44 & 21,128 & 0,044 & $*$ \\
\hline D-K & 330,33 & 78,510 & 0,012 & $*$ \\
\hline F-B & 90,965 & 25,862 & 0,037 & $*$ \\
\hline F-R & 473,41 & 37,306 & 0,026 & $*$ \\
\hline G-P & 424,65 & 30,230 & 0,032 & $*$ \\
\hline $\mathrm{H}-\mathrm{O}$ & 119,14 & 128,00 & 0,008 & $*$ \\
\hline H-P & 116,82 & 55,990 & 0,017 & $*$ \\
\hline J-B & 256,57 & 448,00 & 0,002 & $* *$ \\
\hline J-D & 258,21 & 60,460 & 0,016 & $*$ \\
\hline $\mathrm{J}-\mathrm{F}$ & 248,08 & 26,570 & 0,036 & $*$ \\
\hline $\mathrm{J}-\mathrm{K}$ & 253,16 & 37,250 & 0,026 & $*$ \\
\hline $\mathrm{J}-\mathrm{O}$ & 242,13 & 19,830 & 0,047 & $*$ \\
\hline $\mathrm{J}-\mathrm{P}$ & 264,50 & 235,11 & 0,004 & $* *$ \\
\hline $\mathrm{K}-\mathrm{F}$ & 411,90 & 970,18 & 0,001 & $* *$ \\
\hline K-R & 383,34 & 26,070 & 0,036 & $*$ \\
\hline M-R & 101,55 & 168,78 & 0,006 & $* *$ \\
\hline O-P & 58,939 & 19,450 & 0,048 & $*$ \\
\hline
\end{tabular}

MS: Mean Square; ${ }^{*} \mathrm{P}<.05 ; * * \mathrm{P}<.01$;

A-D: Codes of taxon; NS: Not Significant

According to the mentioned statistical results derived in this study, there is a considerable relation between the investigated taxa, except for I, L, N and S.

Also, it is that there are close relationships among (A, B, D, E, F, $\mathrm{G}, \mathrm{H})$ which also are close taxa as systematically. On the other hand, there is no statistical relationship between some of the taxa examined which also are the most distant taxa as systematically among the investigated. The taxa mentioned are endemic and are symbolized by $\mathrm{C}, \mathrm{K}, \mathrm{I}$., N, T.

In the study, according to both the method, for investigated micromorphological characters coded as $1-4$, positive statistically significant correlations between 1 and 2, 1 and 3, 2 and 4, 3 and 4 were observed (Table 4,5). The highest similarity (for both the method) was revealed between 3 and 4 (lower epidermis width and lower epidermis length).
As the results of this study show, the quantitative micromorphological characters such as lower epidermis width and lower epidermis length are the most appropriate taxonomical characters that can be used to separate taxa.

Similarly, some researchers have studied the leaf anatomical features of 10 different Salvia species growing in the northeast of Iran. They suggested that according to results, the shape of midribs outline was recognizable between the studied species [8].

Consequently, by the analysis of investigated taxa from the leaf micromorphological related characters, it has been determined that lower epidermis width and lower epidermis length are the best characters pairs which represents the variations in them. It has been also found that the results from numerical analysis of the micromorphological characters can provide distinct evidence. 


\section{References}

[1] Firat M. Stachys semsurensis (Lamiaceae), a new species from Adlyaman province (Turkey) belonging to section. Infrarosularis. Phytotax, 2021. 511: 275-82.

[2] Hedge IC. Lamiaceae of south-west Asia: diversity, distribution and endemism. Proc Royal Soc. B.1986. 89: 235.

[3] Yaris, E.L., B. Adsız, I. Yener, E. Tuncay, MA. Yilmaz, Isolation of secondary metabolites of two endemic species: Salvia rosifolia Sm. and Salvia cerino-pruinosa Rech.f. var. elazigensis (Lamiaceae). J. Food Meas 2021; 1-10.

[4] Baytop, T. Therapy with Medicinal Plants in Turkey. Istanbul University Press, Istanbul, 1984.

[5] Singh, B., B. Singh, A. Kishor, S. Singh, MN. Bhat, Exploring plantbased ethnomedicine and quantitative ethnopharmacolog: Medicinal plants utilized by the population of Jasrota Hill in Western, Himalaya. Sustainability; 2020.12: 7526.

[6] Tundis, R., M. Leporini, M. Bonesi, S. Rovito, NG Passalacqua. Salvia officinalis L. from Italy: A comparative chemical and biological study of its essential oil in the mediterranean context. Molecules; 2020.25: 5826.
[7] Özdemır, A., A.Y. Özdemır., K. Yetısen, Statıstıcal Comparatıve Petıol Anatomy of Salvia Sp. Planta Daninha, Viçosa-Mg, V. 34, N. 3, P. 2016. 465-474.

[8] Mousavı S.M., A. Jafarı, S. Najafi, Anatomical and micromorphological studies on leaves of salvia l. species in ne Iran. Romanian Biotechnological Letters Vol. 19, 2014. No1.

[9] Kharazian, N. Morphometric study of some Salvia L. (Lamiaceae) species in Iran. Scientific Journal of Biological Sciences 1(6) 2012.126-137.

[10] PH. Davis, RR. Mill, K. Tan, "Flora of Turkey and the East Aegean Islands” Vol X. Edinburgh: Edinburgh University Press; 1988.

[11] S. Heneidak, A. Samai, M. Shaheen, "Characteristics of then proximal to distal regions of the petioles to identify 15 tree species of Papilionoideae-Fabaceae. Bangladesh J Plant Taxonomy.;14:101-15. 2007.

[12] C.R. Metcalf, L. Chalk, Anatomy of The Dicotyledons, Oxford. Clarendon Press, Vol: 2. 1972.

[13] Kocsis, M., J. Darok, A. Borhidi Comparative leaf anatomy and morphology of some neotrophical Rondeletia (Rubiaceae) species. Plant Syst Evol. 2004. 248:205-18.

[14] Olowokudejo, J.D. Taxonomic value of petiole anatomy in the genus Biscutella L. (Cruciferae). Bull Jard Bot Nat Belg.; 1987. 57:307-20. 